The Quarterly Journal of Austrian Economics

VOLUMe 22 | NO.4 | 565-578 | WiNTER 2019 WWW.QJAE.ORG

\title{
ROTHBARD ON THE ECONOMICS OF SLAVERY
}

\author{
MARK THORNTON*
}

JeL Classification: B53, N31, N91

Aвstract: Murray Rothbard wrote an unpublished note in the early 1960s on the economics of antebellum slavery. Essentially, it was a criticism of the methodology of the New Economic History, or cliometrics, of which Conrad and Meyer (1958a) was the breakthrough application, on the topic of the profitability of slavery. Rothbard points out that their procedure in no way supports their conclusion that slavery was profitable or their ideological conclusion that the Civil War was necessary to end American slavery.

\begin{abstract}
manuscript was found in the Rothbard Archives titled "A Note A on the Economics of Slavery." It appears to be an unpublished communication concerning an article and comment that appeared in the Journal of Political Economy. Given the dearth of analysis of the economics of slavery in Murray N. Rothbard's writings and the revolution in the subject matter that was taking place at the time it was written, the manuscript is certainly worth publishing at this time. ${ }^{1}$ The purpose of this article is to provide the necessary context in which the note was written.
\end{abstract}

* Dr. Mark Thornton (mthornton@mises.org) is senior fellow at the Mises Institute and serves as the book review editor of the Quarterly Journal of Austrian Economics.

${ }^{1}$ By 1956, Rothbard had planned to write about the economic analysis of slavery as an appendix to a chapter on government intervention in his treatise Man, Economy and State (1962). According to Stromberg, the editor of the 2004 edition of Man Economy and State, in a private memo, Rothbard outlined the contents of that appendix and that sketch mimics the contents of Rothbard's (1960) note. 
In 1994, I published a paper on the economics of slavery, "Slavery, Profitability, and the Market Process," in the Review of Austrian Economics, then edited by Rothbard. He had encouraged me to write on the economics of antebellum slavery based on comments I made during an impromptu debate I had with economic historian Robert Higgs at Mises University in the early 1990s.

Not only did Rothbard encourage me to write the article, he guided me with multiple single-spaced pages of references and suggestions. In the process I examined an enormous amount of literature on the economic issues of slavery in antebellum America. It could have easily turned into a second dissertation. However, there was nothing written by Rothbard himself among those recommended sources.

When I was writing, I was well aware of one of the articles that Rothbard commented on in the note. It was a landmark study in the "New Economic History" by Conrad and Meyer that was published in the Journal of Political Economy in 1958. However, I was unaware of the comments by Douglass Dowd (1958) and John E. Moes (1960), which were published in the same journal. The second comment is the direct subject of the Rothbard note. Conrad and Meyer published two revealing replies to both comments. This literature is reviewed here to provide the context of Rothbard's note.

We assume that Rothbard's note was submitted and rejected, if for no other reason, because it would have been submitted more than two years after the original article was published. Also, the "note" would have been the third comment on the article, and no other article in the JPE during this period had more than one published comment. For now, I will note that Rothbard did not bring my attention to either the Moes comment or his own note during the process of researching, writing, or publishing my 1994 article. Both would have been helpful, welcome additions to my research. Moes (1960) argues against the seminal article by Conrad and Meyer, a precursor to the classic and highly controversial work by Robert Fogel and Stanley Engerman, Time on the Cross (1974). Rothbard supplements Moes with a more theoretical commentary. It is worth noting here that the Conrad and Meyer (1958a) article was the epicenter of a methodological revolution in economic history. 
The Conrad and Meyer article is an attempt to establish whether or not antebellum slavery was in fact profitable. At thirty-five pages, it is an empirical analysis of the available data, much like an historical accounting exercise with the assistance of economic modeling. This article marks the very beginning of cliometrics, a.k.a. the New Economic History, in which economic history would be studied primarily using models and statistics. It was a revolution that would eventually sweep the field of traditional economic history.

Conrad and Meyer's article is an effort to measure the ordinary profitability of slavery using an economic, as opposed to an accounting, formula of profit. In addition to the revolutionary method, the article confronted a critical ideological issue at the time: can the American Civil War be justified? Was slavery inefficient and unprofitable and would it have soon died off, making the American Civil War unnecessary? Or, was slavery efficient and profitable, thus necessitating, or at least justifying, the war? Rothbard represents a view that slavery is narrowly profitable (due to external forces) but inefficient and could plausibly and quickly wither away.

Conrad and Meyer begin with a production function for slave-based agriculture (i.e., cotton) and a production function for slave breeding as the joint product of slavery. They then bring together various data to examine the cost and the value of slave production in terms of cotton and slave breeding. They conclude that the joint product of slave labor in terms of crop production and slave breeding exceeded the returns on alternative investments and therefore that slavery was profitable.

That they find that slavery was profitable is not surprising, as any ongoing risky business should produce an ongoing positive return. This would be especially true in an expanding business such as cotton, which along with coal and iron was a primary raw material during the Industrial Revolution! The fact that prices were high and output was rising circa 1849-60 is a strong indication that the market for slaves was not in any kind of long-run equilibrium but instead was experiencing sustained increases due to increasing demand for cotton and other forces.

Their result of profitability is not surprising, because any good, factor of production, or institution that remains in use over a significant period of time must be profitable in some sense. The 
laws of economics dictate this result. However, in the long-run equilibrium economy, or evenly rotating economy, economic profits should always be bid away.

This might not be true for things that provide psychic income, which offsets the lack of monetary profits, but it is only true until losses consume all the invested capital. Therefore this would not be an equilibrium situation. Or it could be that cross subsidies maintain an unprofitable operation in order to provide support for a profitable operation. For example, the owner of an apartment building might continue to operate an unprofitable laundry service on the premises because it increases the demand for the apartments or generates "good will" with tenants.

But what could the logic be with antebellum slavery? Did the slave owners get some kind of psychic income from slave ownership? Did they enjoy whipping their slaves? Or did they feel some kind of personal obligation to maintain slave ownership? Such arguments have been made about antebellum slavery, including by Moes (1960), but it seems doubtful that under ordinary conditions, such concerns could be maintained for centuries and over multiple generations.

In any case, those arguments fail, because the number of slaves continued to grow. Slave markets continued to grow and were increasingly vibrant and resilient during the late antebellum period. There was also an increasing long-term trend in inflation-adjusted slave prices. This evidence suggests that such psychic reasons could not be an important factor here, if they existed at all.

However, the fact that Conrad and Meyer (1958a) found slavery to be profitable satisfies their desire to justify the American Civil War:

In sum, it seems doubtful that the South was forced by bad statesmanship into an unnecessary war to protect a system which must soon have disappeared because it was economically unsound. This is a romantic hypothesis which will not stand against the facts. (Conrad and Meyer 1958a, 121)

Moreover, they also blame "inexorable economic forces" for the stability of slavery from the "strict economic standpoint."

Furthermore, the American experience clearly suggest[s] that slavery is not, from the strict economic standpoint, a deterrent to industrial 
development and that its elimination may take more than the workings of inexorable economic forces. (Conrad and Meyer, 1958a, 122, emphasis added)

They reiterate in the closing paragraph of the article that slavery is the fault of the market, that the market would continue to support slavery, and that ending slavery would necessarily require "the adoption of harsh political measures," i.e., the American Civil War.

To the extent, moreover, that profitability is a necessary condition for the continuation of a private business institution in a free-enterprise society; slavery was not untenable in the ante bellum American South. Indeed, economic forces often may work towards the continuation of a slave system, so that the elimination of slavery may depend upon the adoption of harsh political measures. Certainly that was the American experience. (Conrad and Meyer 1958a, 122, emphasis added)

The first comment on the Conrad and Meyer article was by Douglas F. Dowd (1958). He challenges Conrad and Meyer for taking a simple and narrow approach to something that is very complex, particularly the question of the lack of economic development in the slave states. More generally, Dowd argues, correctly, that the institution of slavery prevented "the basic elements of a capitalist society" from taking root. He notes that the maintenance of slavery in the "land of the free" required the development of an "irrational ideology" which had a pervasive impact on society. Dowd writes:

The authors argue as though slavery were merely another, more manipulable, form of labor; as though it were, one might say, institutionally neutral. And, working essentially within the methodology of neoclassical economics (with time allowed in occasionally) they have analyzed the "economic" meaning of slavery as though they were analyzing the representative firm in the long run (or even, at times, in the short run). (Dowd 1958, 441)

In other words, although Dowd agrees that slavery was profitable, he finds that result largely insignificant compared with the impact of the institution on Southern society, particularly its displacement of capitalism and its drag on economic development. In a different context, it could be argued that dealing illegal drugs on the streets is profitable, but that fixes our attention on an obvious and irrelevant aspect of this issue (of course it must be profitable 
in some sense) and disregards all the real problems (e.g., crime, corruption, overdose deaths, violence, among others).

In their reply, Conrad and Meyer (1958b) do not disagree with Dowd, but rather claim that he is commenting on issues that were beyond the scope of their paper. They reemphasize that their result "means that the imminent demise of slavery in the ante bellum South must be argued on grounds other than unprofitability from now on." This is a curious claim given such facts as the steam tractor's development in the 1870s and its full commercialization during the first quarter of the twentieth century. Would slavery have survived this development?

The true economic question, if not the only important question, is why slavery was profitable. Conrad and Meyer essentially bypass the economic question. They attribute the cause of the profitability to murky and ill-defined "market forces." As we will see, Rothbard asks the right question.

The second comment was by John E. Moes (1960). It is a brute-force frontal assault on Conrad and Meyer (1958a). He argues that the decline of slavery in Rome depended on voluntary manumission, i.e., granting a slave freedom, but that manumission was not a widespread procedure in the antebellum South. According to Moes (1960, 185) "it remained a very minor affair" for the following reasons:

1. Antimanumission laws restricting or prohibiting the freeing of slaves

2. Racial prejudice and white supremacy

3. Freed slaves' very precarious legal status (unlike in Rome)

4. Antiabolitionist ideology turned slave owning from a business into a calling. The ideology made manumission unprofitable in a real sense due to personal repercussions from family, friends and neighbors.

Moes suggest that with free manumission, the relative inefficiency of slaves (without prospects for freedom), and the increasing diversification of the Southern economy, slavery would certainly have declined or disappeared altogether. In other words, if slaves could buy their freedom and that of their family and friends, then leased slaves would work harder and save their income to make purchases of freedom. They would try to get themselves leased by their owners 
into higher-paying industries, such as manufacturing and railroads, and high-skill occupations, such as blacksmithing and telegraph operation. Based on historical experience, Moes thinks that this would have been more profitable for slave owners too, generating higher returns compared to slave-based agriculture. This argument undermines the ex post facto argument that the American Civil War was necessary to end slavery in the antebellum South.

In their reply to Moes, Conrad and Meyer $(1960,187)$ note that Moes's concerns were beyond "our original discussion of the economics of slavery in the American South." Their main concern was to test the hypothesis that slavery as it existed in the antebellum American South was profitable according to the "private-enterprise standards of the period." Again, they simply ignore relevant and important issues and subtly place the blame for slavery on private enterprise.

One can well image that Rothbard would be opposed to Conrad and Meyer for several reasons, methodological, theoretical, and historical, among others. Their linking of slavery with capitalist institutions would obviously be unacceptable to him or any good historian of the subject, as slavery has historically been the result of war, not commerce. Antebellum slavery was hardly a capitalist institution: African states were the largest slave hunters, the Royal African Company (founded by the English monarchy) was one of the largest transporters of slaves to the New World, and slavery only survived in the Southern states due to an extensive system of government intervention made up of slave codes, slave patrol statutes, fugitive slave laws, etc.

The first argument that Rothbard makes in the manuscript is that the true economic profits of slavery occurred in the past, when slave hunters and traders exploited the original supply of slaves. The original price would have reflected the anticipated present value of the flow of net revenues over time. The price would have also included the anticipated present value of the net revenues from slave breeding. In the long run, even slave hunting would only yield a normal market return on investment. Rothbard is arguing from a long-run equilibrium view that in the short term slave hunters could earn an economic profit while subsequent owners would only earn a normal operating profit ceteris paribus. 
What this means is that any detection and measurement of economic profits in a short-run disequilibrium situation in the real world would be the result of some factors other than slavery per se. For example, both Rothbard (1960) and Moes (1960) note that antimanumission laws passed in slave state legislatures were a key element in preventing the withering away of slavery. Rothbard also notes that the constitutional measure to shut down international trade in slaves increased the profitability of slave breeding.

Other exogenous factors-including the US Constitution's slave clause, the 1793 Fugitive Slave Act, the invention of the cotton gin in 1793, the Industrial Revolution, the expansion or strengthening of slave codes and slave patrol statutes (laws designed to prevent runaways by socializing the costs of slave security), and of course the passage of the Fugitive Slave Act of 1850-also increased the profitability of slave-based agriculture. The invention of the farm tractor, the weakening of slave codes (especially the antimanumission laws), and Southern secession and the likely repeal of the Fugitive Slave Act would all have decreased profitability and increased the likelihood of the breakdown of slavery.

Relative to Ludwig von Mises's (2003, 239) topology of malinvestments in capital, antebellum slave labor could qualify as a capital malinvestment in three of five possible cases. First, it could be classified as labor that was economically justified at one time but in the future would no longer be justified because of the rise of new methods, e.g., the adoption of farm machinery. Second, it could become economically unjustified due to other changes in the market data, e.g., a decrease in slave security or a decrease in the demand for the product of the labor. Third, it could be classified as labor that was uneconomic but could still be used "by virtue of interventionist measures that have now been abandoned," e.g., by repealing antimanumission laws and adapting the land tenure system to more profitably exploit the labor.

Rothbard therefore makes two main points in his note. First, slavery itself was not economically profitable past the early slavehunting stage and was more generally inefficient; it was other factors that made slave-based cotton agriculture highly profitable in the antebellum period. Second, political forces were the primary factor keeping the system from withering away. This second point is what I 
expanded on in my 1994 paper and other publications on this topic. ${ }^{2}$ Therefore Rothbard (1960), Moes (1960), Dowd (1959), Hummel (1996), Tullock (1967), myself, and many others are in a tradition that concedes that slavery is potentially "profitable" but otherwise inefficient and requires government support to remain viable.

In conclusion, Rothbard, writing from the vantage point of economic theory, asked the correct economic question and provided the correct answers to the fathers of the "New Economic History" at the time of its birth. Rothbard was not opposed to mathematics or statistics in economic articles and books. In fact, in a private memo written around this time (2010a, May 1961), he criticizes two mainstream economists for the dearth of basic statistics, among other things, in their book on American history. ${ }^{3}$ Rather his primary criticism is a fundamental attack on the methodology of the New Economic History and the subsequent dangerous ideological conclusions that are drawn from it, e.g., that war does good things for society. Historiography might have been different had the editors of the Journal of Political Economy decided to publish his note.

\section{REFERENCES}

Conrad, Alfred H., and John R. Meyer. 1958a. "The Economics of Slavery in the Ante Bellum South." Journal of Political Economy 65, no. 2: 95-130.

_ . 1958b. "The Economics of Slavery in the Ante Bellum South: Reply." Journal of Political Economy 66, no. 5: 442-43.

_ 1960. "The Economics of Slavery in the Ante Bellum South: A Reply." Journal of Political Economy 68, no. 2: 187-89.

Dowd, Douglas F. 1958. "The Economics of Slavery in the Ante Bellum South: A Comment." Journal of Political Economy 66, no. 5: 440-42.

Ewing, Brad, Mark Thornton, and Mark Yanochik. 2001. "A New Perspective on Antebellum Slavery: Public Policy and Slave Prices." Atlantic Economic Journal 29, no. 3: 330-40.

\footnotetext{
${ }^{2}$ See Thornton (1994), and Brad Ewing, Mark Thornton, and Mark Yanochik (2001, 2003a, and 2003b).

${ }^{3}$ For a fuller version of his critique, written in a private unpublished memo at the time, see Rothbard (2010b, September 1961).
} 
. 2003a. "Railroad Construction and Antebellum Slave Prices." Social Science Quarterly 84, no. 3: 723-37.

- 2003b. "Railroad Construction and Antebellum Slave Prices, Rejoinder and Extension." Social Science Quarterly 84, no. 3: 723-37.

Fogel, Robert W., and Stanley L. Engerman. 1974. Time on the Cross: The Economics of American Negro Slavery. New York: W. W. Norton and Company.

Hummel, Jeffrey Rogers. 1996. Emancipating Slaves, Enslaving Free Men: A History of the American Civil War. Peru, Ind.: Open Court Trade and Academic Books.

Mises, Ludwig von. [1960] 2003. Epistemological Problems of Economics. Princeton, N.J.: D. Van Nostrum Co.

Moes, John E. 1960. “The Economics of Slavery in the Anti Bellum South: Another Comment." Journal of Political Economy 68, no. 2: 183-87.

Rothbard, Murray N. 1960. "A Note on the Economics of Slavery." Rothbard Archives. Auburn, Ala.: Mises Institute.

-_. $[1962,1970]$ 2004. Man, Economy, and State with Power and Market. Scholar's ed., ed. Joseph Stromberg. Auburn, Ala.: Ludwig von Mises Institute.

- 2010a. "Report on George B. DeHuszar and Thomas Hulbert Stevenson, A History of the American Republic, 2 vols.," Sept. 1961. In Strictly Confidential: The Private Volker Fund Memos of Murray N. Rothbard, ed. David Gordon. Auburn, Ala.: Ludwig von Mises Institute.

- 2010b. "Review of Douglass C. North, The Economic Growth of the United States, 1790-1860," May 1, 1961. In Strictly Confidential: The Private Volker Fund Memos of Murray N. Rothbard, ed. David Gordon. Auburn, Ala.: Ludwig von Mises Institute.

Thornton, Mark. 1994. "Slavery, Profitability, and the Market Process." Review of Austrian Economics 7, no. 2: 21-47.

Tullock, Gordon. 1967. "The Economics of Slavery." Left and Right 3, no. 2: 5-16. 


\section{A NOTE ON THE ECONOMICS OF SLAVERY}

\section{Murray N. Rothbard}

Professor Moes, in his illuminating contribution to the discussion of the economics of slavery, points out that slavery has an inherent tendency to wither away because the keen incentive of working to buy one's freedom will foster the practice of selling manumission to the slave, a practice profitable to master and slave alike. ${ }^{4}$ There is another economic factor operating also to make slavery unprofitable, which Moes does not mention. And this is the fact that the price of any capital good on the market, will always tend to equal the discounted value of the sum of future net earnings from that capital. In the slave economy, of course, slaves are capital. Therefore, the price of slaves will tend to equal the discounted value of the sum of future net returns that the master is expected to gain from exploiting the slave's labor. Any rise in returns from slaves will raise the slave price. Therefore, since the rate of net return in every business and from every piece of capital on the market, including slaves, tends to be the same, the profit from exploiting slave labor will be imputed backward, from the slaveholder, to the slave trader, and eventually to the slave hunter. Only the slave hunter, therefore, the original person who converted a free man into a slave, reaps a long-run economic gain from slavery; the current slave-master earns only the usual "natural interest" rate of return that every business earns in the long run.

In their reply to Moes, Professors Conrad and Meyer assert that the particular factor making slavery profitable in the South was a high return on slave breeding. ${ }^{5}$ But in the natural course of the market, the particular breeding-productivity of any slave would have been discounted in the original slave price that the master paid for the slave-ancestors. For the price of a slave bought from a trader (ultimately from the hunter), included the expected future value of the increase of slave population from slave-breeding. In short, slave-breeding was just another productive return which the market price of slaves would have discounted. To deny this, we

${ }^{4}$ John E. Moes, "The Economics of Slavery in the Ante-Bellum South: Another Comment," Journal of Political Economy LXVIII (April, 1960): pp. 183-87.

${ }^{5}$ Alfred H. Conrad and John R. Meyer, "Reply," ibid., pp. 187-89. 
would have to say that the slave hunters and traders were systematically and persistently less able and insightful entrepreneurs then the final slave-masters, and there is certainly no reason to make such an assumption.

In the long run, in fact, even slave-hunting will be unprofitable. For if the slave hunting business enjoys the extra imputed profit of slave-exploitation, then more people will flock to slave hunting and the increased competition will raise the costs of slave-hunting, and lower slave prices, until the long-run fate of net return is no greater in slave hunting than in any other industry. And this is why the business of slavery can only continue to be profitable when the supply of slaves is replenished suddenly and fitfully, from non-market resources, e.g., from wars, which can surmount, for a time, the limiting forces of competition.

It should be clear that the supply of new slaves will come only from two sources: external people newly-enslaved, and domestic breeding. For it is difficult to see how any stable society can exist where domestic free citizens are continually enslaved. Such a condition would certainly bring about a perpetual "war of all against all" with everyone trying to enslave everyone else, and an end to any sort of civilization. The newly-enslaved must therefore originate from beyond the borders. War, of course, is an ideal method of building fresh supply, because the ethic engendered by wa[r $]^{6}$ leads to the idea that the one's prisoners are one's to command. When, therefore, as Moes, Conrad, and Meyer agree, the drying up of external sources of supply caused slavery to decline in the Roman Empire, this too demonstrated the inherent economic weakness of slavery, and the natural tendency of the backward-capitalization of slave prices and the equalization of rates of return, to eliminate the exploitation-gains of slavery. A system, in short, where no one-master or even slavehunter-gains, and the slaves themselves definitely lose, is a system where new supply will dry up and the incentives of voluntary manumission will cause slavery to wither away. Only prisoners taken in war can temporarily reverse this decline.

In the case of slavery in the South, Moes has pointed out how anti-manumission laws greatly slowed the process of decline. There

${ }^{6}$ Original reads "way." 
were also other factors. After 1808, the outlawing of the slave trade paradoxically made the withering process much more difficult, for it meant an effective crippling of the slave market. With the slave market hobbled, domestic slaveholders could only increase their supply by domestic breeding — and any increase in the rate of breeding could no longer be fully capitalized backward in the prices of purchased slaves. Hence, the gains from higher productivity of breeding were no longer imputed backward to the slave traders and slave hunters. Thus, given a rise in breeding rates, the constitutional prohibition of the slave trade helped perpetuate slavery at home. Before 1808, another factor delayed the onset of competitive decline and kept the slave trade profitable longer than it would have been. For many slaves were not so created by the slave-hunters, but instead were bought from their existing "slave-masters," the tribal chieftains of Africa. And since the tribal chieftains were outside the market framework, and were therefore poor entrepreneurs, the slave traders were able to reap great gains from the trade and leave the chieftains with a much lower return than they could have obtained. Of course, even these gains would have been competed away in the long run, but the fact the chieftains were the original enslavers delayed the process of eliminating the exploitation-gains of slavery.

Conrad and Meyer conclude their reply by chiding the Roman Empire for not realizing the rich gains of slavery, presumably from slave-breeding. But [A. H. M.] Jones has shown, in an important and neglected article, that slave-breeding in the Roman Empire, after the Pax Romana had ended the great wars (as well as that other main source of external slaves-piracy), was a costly and ineffective business. When not breeding, after all, the female slaves were largely a net liability, while children were per se a total loss, especially since so many children of ancient days died before reaching working age. That slave breeding was a shaky affair may be seen by the government laws and regulations trying to prop it up. For example, Rome decreed in 52 A.D. that if a free woman cohabitated with a slave, the slave's owner was entitled to claim ownership of her-and her subsequent offspring. Here was a clear-cut attempt to prevent slaves from breeding outside of the slave framework. Moreover, the emperors decreed that any infants of free parents abandoned and brought up as slaves could not be reclaimed by their parents unless the latter repaid the costs of 
rearing the children. Augustus would not free any of his personal slaves until they had produced slave-sons to substitute for them in his service. In such ways did the Roman Empire try to shore up the dwindling supply of bred slaves. ${ }^{7}$ Even aided by these laws, breeding was unsuccessful, and slavery gave way to the processes of voluntary sale of manumission.

${ }_{7}$ A.H.M. Jones, "Slavery in the Ancient World," The Economic History Review IX (April, 1956): pp. 185-99, especially pp. 190-97. Jones also points out that only widespread piracy, kidnapping, and perpetual inter-tribal wars permitted slavery to flourish in Athens. 